\title{
Governance of Gender Diversity Case
}

\author{
by Beatrix Dart \\ (Canada)
}

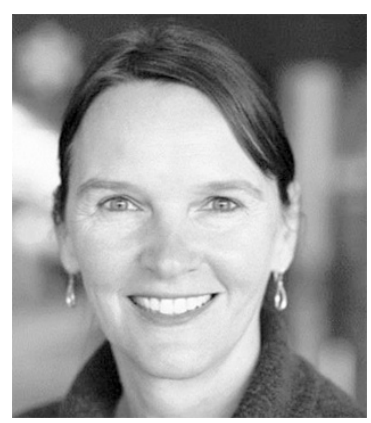

Rotman School of Management, University of Toronto International Center for Corporate Governance

The six board directors of Minefield Company, a publicly traded mining company with a successful 40-year international track record and revenues in excess of $\$ 12$ billion dollars, have been locked in a heated debate over the last few board meetings. The board chairman, John Miller, has been visibly frustrated by the lack of agreement what criteria they should use to add a new board member to their currently all-male board. Since Jim's retirement from the board, the position has remained vacant for over 9 months now. The CEO of Minefield, Barry Goodman, has been adamant that they should be adding a woman to their board, citing that it is "the right thing to do given that we are in the twenty-first century."

Peter Conway, who at the age of 61 is one of the "younger" board members, has repeatedly pointed out that investors have started to ask more specific questions about their board composition — all white male, with an average age of 69 yearsand their lack of tenure limits. Gender diversity has been brought up by one of their largest shareholder as a proposal to enhance their diversity of thought on the board, which is considered as too homogenous.

However, Gordon Dey, one of the longest-serving board members, feels that this is the wrong way to go about adding diversity to the board. His argument is that first of all it shouldn't be based on gender, but on merit- "who wouldn't want the most qualified and experienced person on their board, and should it happen to be a woman-great (!), but let's focus on qualifications first. So who knows a former CEO with mining industry experience in their network?"

Charles Jenkins, a former senior accountant, is not sure which might be the best approach. Clearly, there are hardly any female CEOs in the mining industry, but if the investors are pushing for more women on boards, shouldn't they make it their first priority to find one? And how would one go about doing that? 
Board member Brian Copper thinks the only fair approach would be to develop a rigorous board skill matrix, identifying the exact skills gaps they have on their board (he believes it is in technology), and then look for the best available person to fill that board seat-male or female.

Finding the discussions all a waste of time, Bill Murton points out that he has a perfectly good candidate for the board seat, Tom Watson. He knows Tom from another board they serve together, and he can vouch that Tom is an experienced board member who will fit right into this board as well. On top of that, Tom has great connections in the exploration business, which could be very useful for the Minefield Company.

What would be your recommendation how to solve the disagreement?

\section{$1 \quad$ What Happened in Reality?}

- Investor pressure was seen as important by the CEO and by most of the board members, and there were concerns of negative PR at the next shareholder meeting if no pro-active gender diversity policies were presented.

- The board members did come around to prepare a board skill matrix that emphasized new skills they felt they were lacking as a board. They also included attributes such as "independent thinker," "intellectual curiosity," etc. which opened up the field of candidates further, and didn't limit themselves to industry experts.

- None of the board members had a suitable female candidate in their immediate network. They therefore agreed to each reach out to professional connections and to share the skill matrix with the request to bring forward names of female candidates.

- To their surprise, they had over 20 names for women within a 2-week period. A few phone calls and lunch meetings led to a short list of three outstanding female board candidates. They decided to add one of them immediately and to keep the other two names on an "evergreen list" as they might be facing further board vacancies in the near future.

- Board meetings changed. There were more discussions on governance and risk measures, and overall the board felt that their decision-making process had improved dramatically.

- A year later, a second woman was added to the board of Minefield as Gordon Dey retired.

\section{$2 \quad$ What Are the Most Important Lessons Learned?}

- Diversity of thought certainly goes broader than gender diversity, but gender diversity is a good place to start to bring fresh perspectives to the board table. 
- Merit-based arguments are welcome and make good sense if there is an equal playing field. However, in most countries without a gender quota for board positions, women have been historically under-represented and under-valued. Therefore, a corrective action is required to establish an equal playing field.

- Finding qualified women to serve on boards requires a conscious effort to expand the network of board members and senior executives. There are other sources such as trusted advisors, lists of board-ready women, executive search firms, etc. which can be tapped. It is not a supply issue, but a demand issue!

- A board skill matrix should not be limited to previous senior position, but also contain desirable attributes of board candidates. Many male board directors started out on a board because somebody took a chance on them-the same should hold true for female board appointees.

- Rigorous board evaluations should take place at regular intervals to assess the performance of each board director and find the right time to bring in a replacement. Ideally, this would eliminate the need for age limits or tenure limits.

- In the best case scenario, boards have an "evergreen list" of desirable board candidates they are keeping an eye on, so that in the event of a vacancy, it can be acted upon quickly.

Open Access This chapter is licensed under the terms of the Creative Commons Attribution 4.0 International License (http://creativecommons.org/licenses/by/4.0/), which permits use, sharing, adaptation, distribution and reproduction in any medium or format, as long as you give appropriate credit to the original author(s) and the source, provide a link to the Creative Commons licence and indicate if changes were made.

The images or other third party material in this chapter are included in the chapter's Creative Commons licence, unless indicated otherwise in a credit line to the material. If material is not included in the chapter's Creative Commons licence and your intended use is not permitted by statutory regulation or exceeds the permitted use, you will need to obtain permission directly from the copyright holder.

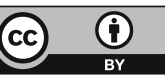

